\title{
RANCANGAN PERBAIKAN TATA LETAK GUDANG BARANG JADI PRODUK STAMPING PARTS PADA PT. CSM BERDASARKAN METODE FUZZY SUBTRACTIVE CLUSTERING ALGORITHM
}

\author{
Annisa Widya Putri dan Iveline Anne Marie \\ Program Studi Teknik Industri Universitas Trisakti \\ e-mail: ptr.putri@hotmail.com, ivelineannemarie@yahoo.com
}

\begin{abstract}
ABSTRAK
PT. CSM merupakan perusahaan yang bergerak di sektor industri otomotif. Stamping parts merupakan salah satu produk unggulan yang dihasilkan oleh PT. CSM. Permasalahan yang dihadapi oleh perusahaan adalah belum optimalnya pemanfaatan ruang gudang barang jadi yang tersedia. Hal tersebut ditandai dengan adanya penempatan produk secara tidak teratur, adanya area pada gudang barang jadi yang difungsikan di luar kegiatan penyimpanan, penempatan produk jadi di luar area gudang karena daya tampung gudang barang jadi kurang maksimal, serta penempatan produk jadi yang mengganggu jalur gang dan saling menghalangi satu sama lain. Tujuan penelitian adalah untuk melakukan analisis dan memberikan usulan perbaikan rancangan tata letak gudang produk jadi pada PT CSM. Pemecahan masalah diawali dengan melakukan evaluasi terhadap kondisi awal gudang barang jadi dengan menggunakan check sheet, perhitungan total biaya perpindahan, total jarak tempuh forklift, dan utilitas penggunaan ruangan. Berdasarkan hasil evaluasi diperoleh total biaya perpindahan pada kondisi awal gudang barang jadi sebesar Rp 264.662,84 per hari dan total jarak tempuh dari pintu masuk gudang menuju area penyimpanan dan dari area penyimpanan ke pintu keluar gudang sebesar 2.336,28 meter. Langkah pemecahan masalah berikutnya adalah melakukan perancangan rak untuk meningkatkan daya tampung gudang. Selanjutnya digunakan algoritma Fuzzy Subtractive Clustering untuk mengetahui hasil pengelompokan tipe stamping parts sesuai dengan kecenderungan keanggotaannya. Hasil perhitungan menunjukkan pengelompokkan tipe produk jadi ke dalam 4 cluster sebagai dasar penempatan produk jadi untuk meminimalkan jarak tempuh dalam pengangkutan produk jadi. Usulan rancangan tata letak gudang barang jadi menghasilkan total biaya perpindahan sebesar Rp 252.982,69 per hari atau penurunan sebesar 4,4132\% dari kondisi awal gudang, dengan total jarak tempuh dari pintu masuk gudang menuju area penyimpanan dan dari area penyimpanan ke pintu keluar gudang sebesar 983,146 meter. Tata letak gudang barang jadi usulan terbaik menghasilkan utilisasi ruangan sebesar $25,078 \%$.
\end{abstract}

Kata Kunci: Fuzzy Subtractive Clustering, Perancangan Tata Letak Gudang, Sistem Rak

ABSTRACT

PT. CSM is manufacturer company running in the the sector of automotive industry. Stamping parts are one of their leading products, which are produced in a make to stock system. The problem occurring in the company's finished goods warehouse is that the available warehouse space area is not being functioned optimally. The problem is detected by unorganized and random finished goods placements, an area inside the warehouse that is used outside the purpose of finished goods storing, finished goods placements outside the warehouse area because of the insufficient warehouse storage capacity, and finished goods placements that interrupt the aisles and block each other. The purpose of the research is analyzing and proposing improvement idea for finished goods warehouse layout design in PT. CSM. Problem is begun to be solved first by evaluating the current condition of finished goods warehouse with check sheet, total transportation cost, total transportation distance of forklift, and warehouse utilization. Based on the evaluation, it is identified that the total finished goods transportation cost are $R p$ 264,662.84 per day and total travel distance from warehouse entry to storage space and from storage space to warehouse exit are 2,336.28 meter. Secondly, the problem is solved by designing a racking system. The reason behind designing a racking system is to utilize the airspace so it will increase the capacity of the warehouse. Third way to solve the problem is applying Fuzzy Subtractive Clustering Algorithm to categorize stamping parts depending on its membership tendency. The algorithm results in products grouping into four different clusters used as a rule for products placement in the warehouse to minimize products travel distances. The best proposed warehouse layout alternative results in total finished goods transportation cost Rp 252,982.69 per day, decreasing about $4.4132 \%$ from the current condition, with total travel distance from warehouse entry to storage space and from storage space to warehouse exit are 983.146 meter. The best proposed warehouse layout alternative also results in space utilization percentage about 49.6\%. The number is higher than the percentage of current warehouse condition, which is only $18.773 \%$. 


\section{PENDAHULUAN}

Gudang merupakan fasilitas pendukung inventory. Perencanaan gudang mempengaruhi kualitas bahan baku dan barang jadi yang diproduksi suatu perusahaan. Penempatan produk jadi yang tidak teratur akan mengakibatkan adanya peningkatan terhadap biaya material handling yang disebabkan oleh peningkatan jarak tempuh dan kesulitan dalam proses penempatan dan pengambilan produk jadi pada gudang. Perancangan dan pengaturan tata letak produk jadi pada gudang akan memperlancar aktivitas penyimpanan produk jadi.

PT. CSM merupakan perusahaan manufaktur yang berlokasi di Jawa Barat, Indonesia, yang bergerak di sektor industri otomotif. Produk-produk yang dihasilkan antara lain adalah dies, jig dan checking fixture, pressed parts, sub assembly parts, fabrications, maintenance services, steel construction, dan kegiatan permesinan (machinery works). Stamping parts merupakan salah satu produk unggulan. Hasil produksi stamping parts telah memiliki konsumen tetap dari perusahaan otomotif besar. Produk ini diproduksi untuk mendukung strategi make to stock. Penyimpanan stok dilakukan di gudang barang jadi yang dialokasikan khusus untuk produk stamping parts.

Gudang barang jadi yang dimiliki oleh PT. CSM berukuran $15 \mathrm{~m}$ x $10 \mathrm{~m}$. Stok disimpan di dalam gudang barang jadi yang dialokasikan khusus untuk produk stamping parts. Berdasarkan hasil pengamatan dan wawancara dengan pihak perusahaan, penempatan produk di dalam gudang barang jadi dilakukan tanpa perencanaan dan cenderung disesuaikan dengan ketersediaan ruangan (space) yang ada pada saat operator ingin meletakkan produk jadi. Kondisi ini memperlambat proses load dan unload dan mengganggu jalur gang sebagai area lalu lintas alat material handling. Alat material handling yang digunakan pada gudang adalah forklift berkapasitas 3 ton.

Gudang barang jadi yang belum menerapkan sistem penempatan barang dengan baik menyebabkan pemanfaatan ketersediaan ruang pada gudang belum optimal. Banyak produk jadi yang diletakkan di lantai tanpa menggunakan pallet karena space yang ada tidak mencukupi apabila menggunakan pallet. Terdapat sejumlah produk jadi yang dipaksakan untuk ditempatkan di satu pallet dengan jumlah yang melebihi kapasitas pallet untuk mengurangi kebutuhan pallet yang harus disimpan di gudang karena keterbatasan ketersediaan area gudang. Terdapat pula produk jadi yang disimpan sementara di area lantai produksi karena area gudang yang tidak mencukupi.

Berdasarkan permasalahan tata letak gudang barang jadi pada PT. CSM, penelitian ini bertujuan untuk melakukan analisis dan memberikan usulan perbaikan rancangan tata letak gudang produk jadi pada PT. CSM.

\section{TINJAUAN PUSTAKA}

\section{Gudang Barang Jadi}

Pada umumnya terdapat 3 jenis gudang, yaitu gudang bahan baku, gudang bahan pembantu, dan gudang barang jadi. Gudang barang jadi yang menjadi fokus pada penelitian merupakan merupakan gudang yang berfungsi untuk menyimpan produk-produk yang telah selesai diproduksi. Aktivitas yang dilakukan pada gudang antara lain adalah receiving, prepacking, putaway, storage, order picking, packaging and/or pricing, sortation, dan packing and shipping. Salah satu prinsip area penyimpanan yang diterapkan di gudang adalah popularity, yaitu minimalisasi jarak tempuh untuk tipe produk yang memiliki tingkat popularitas tinggi [1].

\section{Material Handling}

Material handling merupakan seni dan ilmu pemindahan, penyimpanan, pengamanan, dan pengontrolan suatu material. Kegiatan material handling bukanlah kegiatan yang produktif, namun berperan sangat penting dan dibutuhkan dalam proses produksi. Pallet dan rak merupakan salah satu cara material handling yang umum digunakan dalam media penyimpanan [1]. 
Rancangan Perbaikan Tata Letak Gudang Barang Jadi Produk Stamping Parts pada PT. CSM Berdasarkan Metode Fuzzy Subtractive Clustering Algorithm

Annisa Widya Putri dan Iveline Anne Marie

\section{Perancangan Rak}

Rak merupakan salah satu alat material handling yang digunakan sebagai media penyimpanan. Dimensi yang harus diperhatikan dalam perancangan rak adalah clear space antara lantai dan langit-langit, dimensi pallet, kedalaman rak, tinggi rak, dan panjang rak. Jenis rak yang digunakan adalah standard pallet rack. Standard pallet rack terdiri dari dua upright frame dan sepasang load beam untuk tiap level atau tingkatan raknya. Standard pallet rack umumnya didesain untuk penyimpanan pallet loads atau produk yang dikemas dengan karton. Bukaan atau opening rak ini terdiri dari satu hingga tiga pallet loads. Rak ini didesain untuk peletakan rak single-deep rows atau saling membelakangi (back to back rows). Pada standard pallet rack, posisi pallet load di tingkat pertama berada di atas lantai (tidak diletakkan di atas load beam, sedangkan posisi pallet load tingkat kedua berada kira-kira 44 hingga 48 in di atas lantai. Jarak kelonggaran antar pallet atau antara pallet dengan upright frames-nya adalah 3 hingga 6 inch [2].

\section{Fuzzy Subtractive Clustering Algorithm}

Fuzzy Subtractive Clustering merupakan salah satu algoritma Fuzzy Clustering yang banyak dikenal. Pada Fuzzy Subtractive Clustering jumlah kelompok yang akan dibentuk belum diketahui sebelumnya. Fuzzy Subtractive Clustering didasarkan atas ukuran densitas (potensi) titik-titik data dalam suatu ruang atau variabel. Pada Fuzzy Subtractive Clustering suatu cluster pasti merupakan salah satu dari data yang dikelompokkan. Konsep dasarnya adalah menentukan daerah-daerah dalam suatu variabel yang memiliki densitas tertinggi terhadap titik-titik di sekitarnya [3].

\section{METODE PENELITIAN}

Penelitian diawali dengan melakukan evaluasi terhadap kondisi awal gudang barang jadi dengan menggunakan material handling audit check sheet, perhitungan total jarak tempuh forklift, perhitungan total biaya perpindahan forklift per hari, dan persentase utilisasi penggunaan area gudang. Selanjutnya dilakukan perancangan rak dengan terlebih dahulu menghitung jumlah produk jadi maksimum per pallet, kebutuhan pallet, dan frekuensi pengangkutan produk jadi. Lalu, dilakukan perhitungan kebutuhan luas gudang barang jadi dan alternatif layout gudang barang jadi berdasarkan rak yang telah dirancang. Selanjutnya dilakukan pengelompokkan tipe produk stamping parts ke dalam cluster tertentu untuk meminimasi biaya perpindahan forklift. Layout usulan terbaik merupakan layout usulan dengan total biaya perpindahan forklift yang paling minimal berdasarkan perhitungan Material Handling Evaluation Sheet (MHES). Layout usulan terbaik tersebut kemudian akan dibandingkan dengan layout kondisi awal gudang berdasarkan total jarak tempuh forklift, material handling audit check sheet, dan persentase utilisasi penggunaan ruangannya. Berikut ini merupakan flowchart penelitiannya:

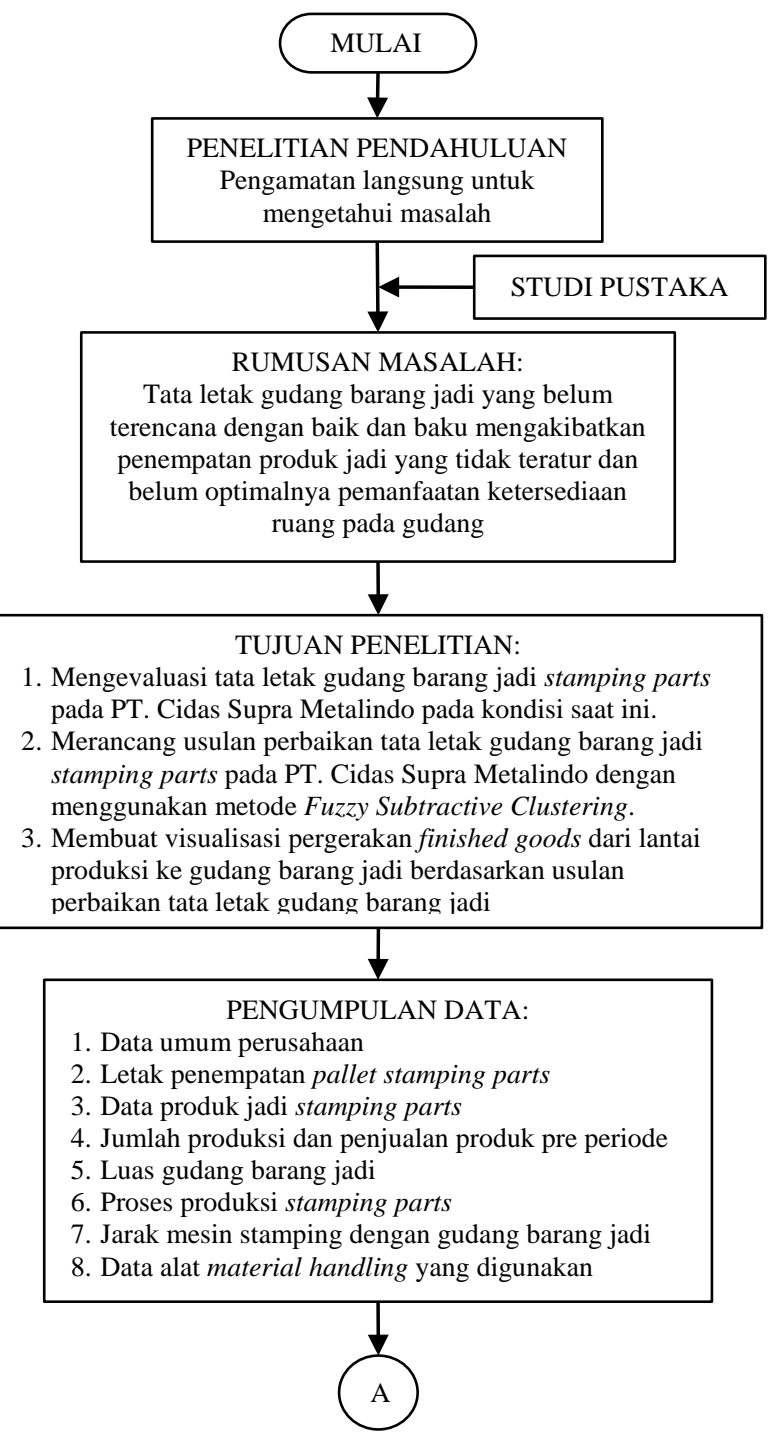

Gambar 1. Flowchart Penelitian 


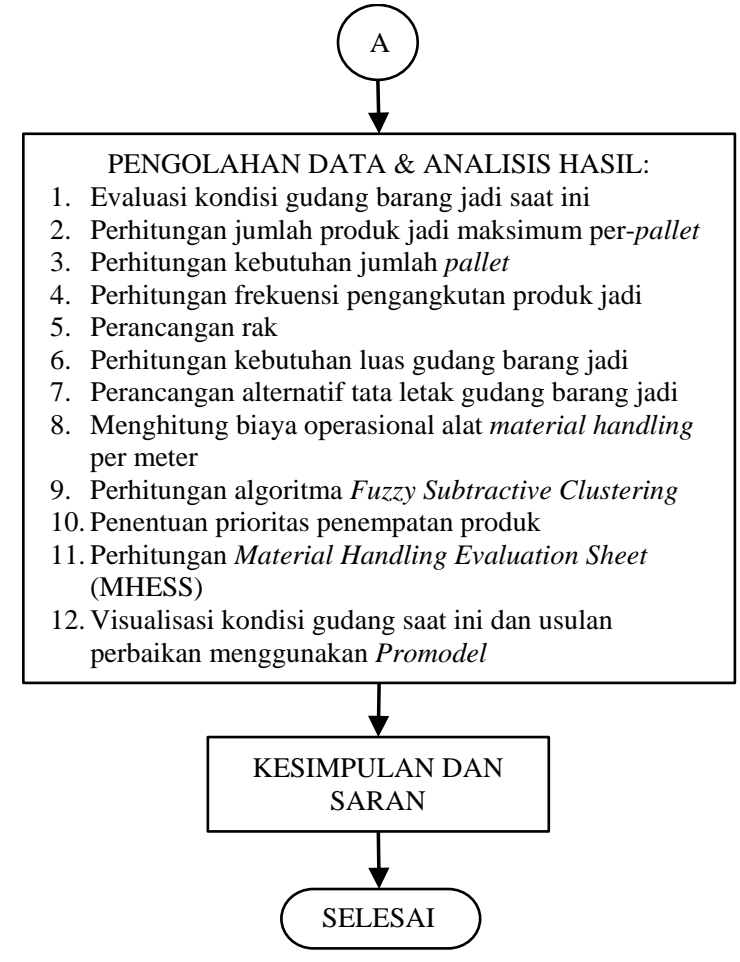

Lanjutan Gambar 1. Flowchart Penelitian

\section{Pengumpulan Data}

Data yang diperlukan dalam penelitian antara lain adalah data umum perusahaan, letak penempatan pallet stamping parts, data produk jadi stamping parts, jumlah produksi dan penjualan produk per periode, luas gudang barang jadi, proses produksi stamping parts, jarak mesin stamping dengan gudang barang jadi, dan data alat material handling yang digunakan.

\section{HASIL DAN PEMBAHASAN}

Evaluasi Kondisi Awal Gudang Barang Jadi

Evaluasi menggunakan Material

Handling Audit Checklist memudahkan penggunanya dalam proses identifikasi permasalahan yang berkaitan pada gudang barang jadi. Pada kondisi awal gudang barang jadi, ditemukan adanya pergerakan material atau produk jadi yang terhambat sehingga menyebabkan delay, yang disebabkan oleh penempatan produk jadi yang saling menghalangi atau menutupi satu sama lain sehingga diperlukan beberapa kali proses pemindahan produk. Alat material handling yang digunakan hanya 1 forklift yang difungsikan untuk mengangkut produk jadi dari lantai produksi menuju gudang dan mengangkut produk jadi meninggalkan gudang. Pada gudang barang jadi, banyak ditemukan produk jadi yang diletakkan secara langsung di atas lantai, tanpa menggunakan alas atau pallet. Penempatan produk jadi dilakukan secara tidak teratur, sehingga menghalangi proses pemindahan produk jadi oleh forklift, yang mengakibatkan meningkatnya biaya operasional forklift. Berdasarkan hasil evaluasi diperoleh total biaya perpindahan pada kondisi awal gudang barang jadi sebesar Rp 264.662,84 per hari dan total jarak tempuh dari pintu masuk gudang menuju area penyimpanan dan dari area penyimpanan ke pintu keluar gudang sebesar 2.336,28 meter. Utilisasi penggunaan ruangan hanya diperoleh sebesar $4,881 \%$.

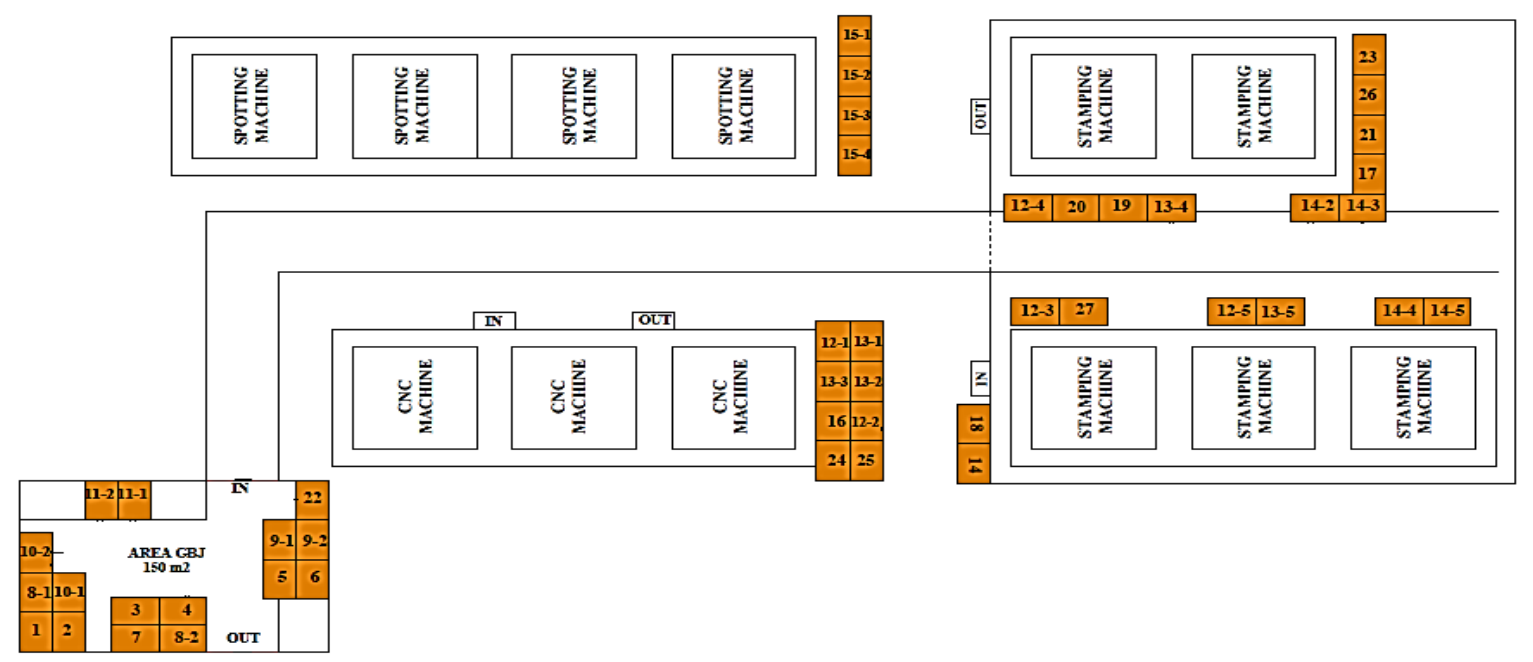

Gambar 2. Layout Penempatan Stamping Parts Kondisi Awal 
Rancangan Perbaikan Tata Letak Gudang Barang Jadi Produk Stamping Parts pada PT. CSM Berdasarkan Metode Fuzzy Subtractive Clustering Algorithm

Annisa Widya Putri dan Iveline Anne Marie

\section{Jumlah Produk Maksimum pada Pallet}

Perhitungan jumlah produk maksimum pada pallet bertujuan untuk menghitung berapa jumlah produk yang dapat ditampung oleh pallet hingga batas maksimal pallet yaitu 2000 kg. Hasil perhitungan tersebut digunakan untuk menghitung berapa jumlah pallet yang dibutuhkan oleh gudang untuk masing-masing tipe produk.

\section{Kebutuhan Jumlah Pallet}

Jumlah pallet yang dibutuhkan untuk masing-masing tipe produk dihitung dengan menggunakan stok maksimum dari masingmasing tipe produk. Jumlah stok akhir tergantung pada jumlah stok awal, jumlah produk jadi yang telah selesai diproduksi dan masuk ke dalam sistem penyimpanan (in), dan jumlah produk jadi yang dikirim ke customer sesuai pesanan (out). Contoh perhitungan untuk produk tipe K-1026, MEMBER, RR SIDE, RH adalah sebagai berikut:

$$
\begin{aligned}
& \text { Jumlah pallet }=\frac{\text { jumlah stok maksimum }}{\text { jumlah produk jadi maks }} \\
& \text { per pallet }
\end{aligned}
$$

\section{Frekuensi Pengangkutan Produk Jadi}

Masing-masing tipe stamping parts yang disimpan di gudang memiliki jumlah pallet yang berbeda-beda. Produk stamping parts yang telah selesai diproduksi kemudian dimasukkan ke dalam pallet, kemudian forklift akan mengangkut pallet tersebut dari lantai produksi menuju gudang barang jadi (in/masuk ke dalam gudang). Forklift juga mengangkut pallet dari gudang barang jadi ke pintu keluar gudang barang jadi menuju area shipping (out / keluar dari gudang). Sebagai contoh untuk produk tipe K-1026, MEMBER, RR SIDE, RH periode 1 , cara perhitungannya adalah sebagai berikut:

\section{Frekuensi in atau out $=$}

$\underline{\text { jumlah produk yang masuk in atau out } \mathrm{x} \text { berat produk }}$ maksimum unit load

Frekuensi in $\quad=\frac{812}{780}=1,041 \sim 2 \mathrm{kali}$

Frekuensi out $=\frac{250}{780}=0,3205 \sim 1 \mathrm{kali}$

\section{Perancangan Rak}

Berdasarkan Mulcahy (1994), salah satu cara yang dapat dilakukan untuk meningkatkan space penyimpanan pada gudang adalah dengan memanfaatkan area 'udara' (airspace) di atas lantai. Salah satu metode yang dapat digunakan untuk memanfaatkan area 'udara' tersebut adalah dengan menggunakan rak (Mulcahy, 1994). Penggunaan rak akan meningkatkan jumlah unit load yang dapat disimpan karena penempatan unit load dilakukan secara vertikal. Hasil perancangan rak adalah sebagai berikut:

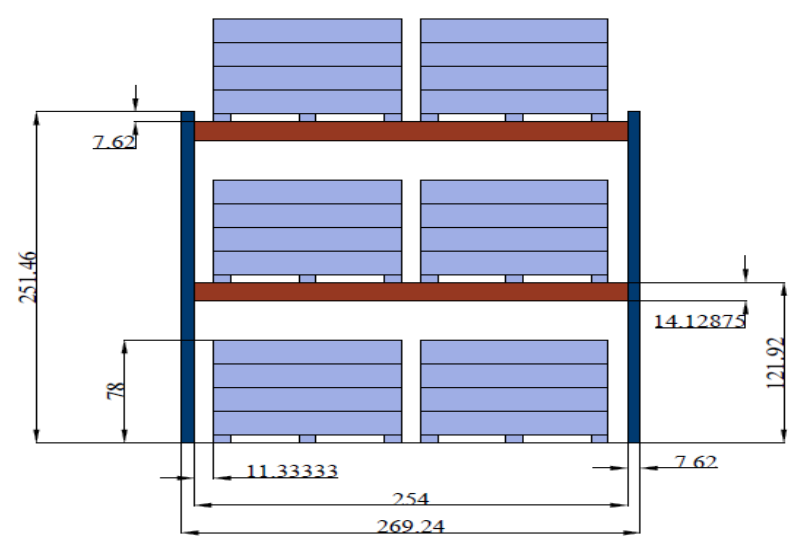

Gambar 3. Tampak Depan Rak (satuan cm, skala 1:1)

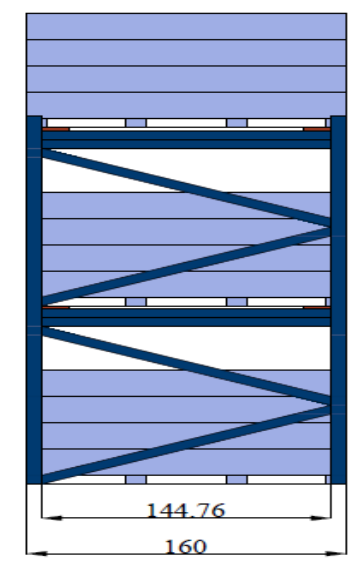

Gambar 4. Tampak Samping Rak (satuan cm, skala 1:1)

\section{Perhitungan Kebutuhan Luas Gudang Barang Jadi}

$$
\begin{aligned}
& \text { Lebar area rak }= 2 r+2 \mathrm{~W}+3 \mathrm{c} \\
&=(2 \times 7,62)+(2 \times 110)+ \\
&(3 \times 11,3333) \\
&= 269,24 \mathrm{~cm}=2,6924 \mathrm{~m} \\
& \text { Panjang area rak }=0,5 \mathrm{~A}+\mathrm{L}+0,5 \mathrm{~F}
\end{aligned}
$$


$=(0,5 \times 350)+160+$

$(0,5 \times 20)$

$=345 \mathrm{~cm}=3,45 \mathrm{~m}$

Luas area rak $=$ panjang area $\mathrm{x}$ lebar area

$=345 \mathrm{~cm} \times 269,24 \mathrm{~cm}$

$=92887,8 \mathrm{~cm}^{2} \sim 9,3 \mathrm{~m}^{2}$

Kebutuhan luas lantai gudang barang jadi

= luas area rak barang jadi $\mathrm{x}$ jumlah rak yang dibutuhkan

$=9,3 \mathrm{~m}^{2} \times 8=74,4 \mathrm{~m}^{2}$

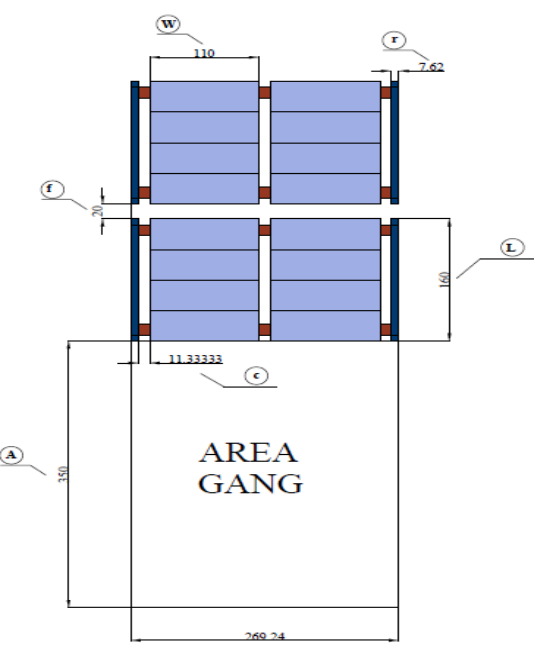

Gambar 5. Tampak Atas Penempatan Rak (satuan cm, skala 1:1)

\section{Perancangan Layout Alternatif}

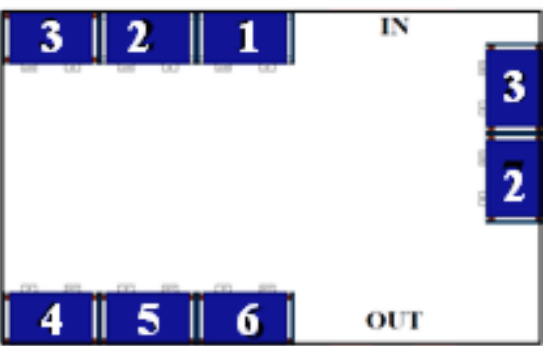

Gambar 6. Layout Alternatif 1

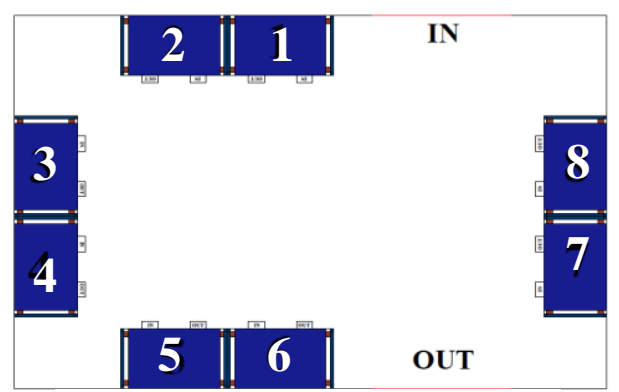

Gambar 7. Layout Alternatif 2

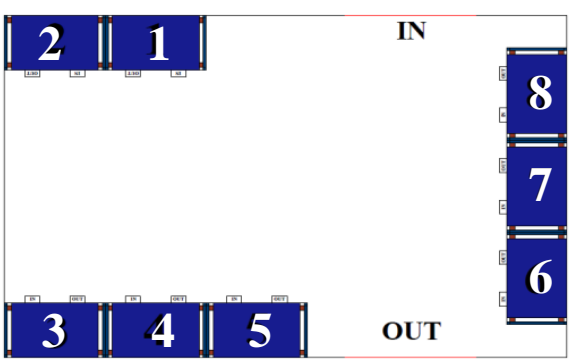

Gambar 8. Layout Alternatif 3

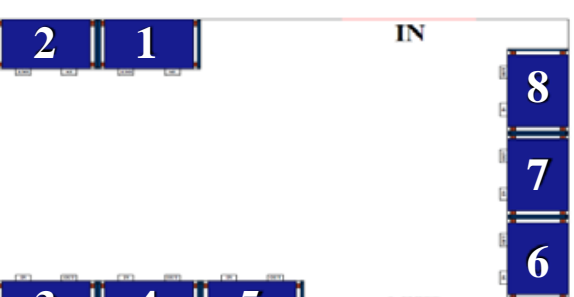

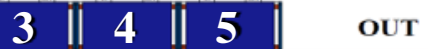

Gambar 9. Layout Alternatif 4

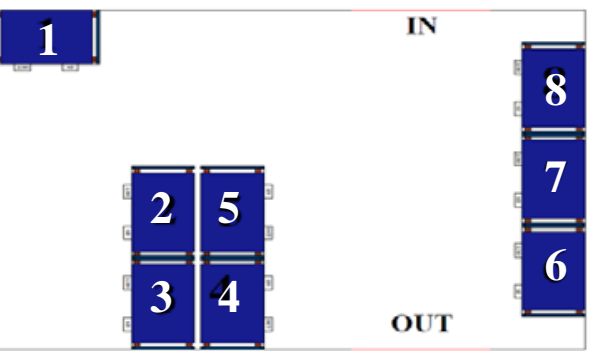

Gambar 10. Layout Alternatif 5

\section{Biaya Perpindahan Forklift per Meter}

Berdasarkan hasil wawancara dengan kepala departemen Warehouse \& Delivery dan departemen Plant Equipment \& Support PT. CSM, diperoleh data mengenai material handling di gudang barang jadi produk stamping part sebagai berikut:

1. Alat material handling yang digunakan adalah forklift merek TCM berkapasitas 3 ton.

2. Kecepatan pemakaian forklift adalah $20 \mathrm{~km} / \mathrm{jam}$.

3. Aktivitas penyimpanan dan pengambilan produk jadi umumnya dilakukan pada hari kerja PT. CSM yaitu hari Senin hingga Jumat, dengan jam kerja per harinya adalah 7 jam, di mana dalam satu bulan terdapat 22 hari kerja.

4. Pengoperasian forklift dilakukan oleh satu orang operator.

5. Upah operator per bulan adalah Rp 2.975.000,00 per bulan. 
Rancangan Perbaikan Tata Letak Gudang Barang Jadi Produk Stamping Parts pada PT. CSM Berdasarkan Metode Fuzzy Subtractive Clustering Algorithm

Annisa Widya Putri dan Iveline Anne Marie

6. Harga pembelian forklift adalah Rp 285.650.000,00.

7. Umur ekonomis forklift adalah 10 tahun.

8. Nilai sisa forklift ketika dijual saat umur ekonomis telah habis diperkirakan Rp 95.000.000,00.

9. Biaya maintenance forklift adalah Rp 475.000,00 per bulan, yang digunakan untuk penggantian oli, pengecekan dan/atau penggantian ban, dan penggantian spare parts apabila ada kerusakan.

10. Jenis bahan bakar yang digunakan adalah solar, dengan harga per liter adalah Rp 11.650,00.

Perhitungan depresiasi alat material handling forklift menggunakan metode garis lurus, karena forklift memberikan kontribusi yang merata selama masa penggunaannya. Depresiasi dihitung dengan rumus:

$$
\begin{aligned}
\text { Depresiasi } & =\frac{\text { Harga Perolehan Aset-Nilai Sisa }}{\text { Umur Ekonomis Aset }} \\
& =\frac{285.650 .000-95.000 .000}{10 \times 12 \times 22 \times 7} \\
& =10316,56 \text { per jam }
\end{aligned}
$$

Bahan bakar yang digunakan oleh forklift adalah solar berjenis solar non subsidi. Harga solar non subsidi ketika periode penelitian adalah Rp 11.650,00 per liter. Dalam satu hari, forklift rata-rata menghabiskan 7 liter bahan bakar solar non subsidi. Sehingga, dalam satu hari, biaya yang dikeluarkan untuk bahan bakar forklift adalah Rp 81.550,00. Dalam satu hari, terdapat 7 jam kerja.

- Biaya bahan bakar forklift per jam-nya adalah: $=\frac{81550}{7}=$ Rp 11.650,00 per jam.

- Upah operator per bulan adalah Rp 2.975.000,00.

- Upah operator per jam $=\frac{2975000}{22 \times 7}=$ Rp19.318,00 per jam

Berdasarkan hasil perhitungan depresiasi, bahan bakar, dan operator material handling, serta data-data material handling yang diperoleh dari hasil wawancara dengan staf pabrik yang bersangkutan.
Biaya material handling per meter

$$
\begin{aligned}
& =\frac{\text { depresiai+biaya maintanance+biaya bahan bakar+upah operator }}{\text { kecepatan forklift }} \\
& \quad=\frac{10316,56+\left(\frac{475000}{22 \times 7}\right)+11.650+19.318}{20 \times 1000} \\
& \quad=\operatorname{Rp} 2,218 \text { per meter }
\end{aligned}
$$

\section{Fuzzy Subtractive Clustering Algorithm}

Langkah perhitungan Fuzzy Subtractive Clustering Algorithm adalah sebagai berikut[3]:

a. Menginput data yang di-cluster, yaitu 27 tipe stamping parts, frekuensi in dan out, biaya perpindahan, dan alokasi pallet

b. Menentukan nilai:

- $\mathrm{R}_{\mathrm{j}}$, merupakan jari-jari berupa vektor yang akan menentukan seberapa besar pengaruh pusat cluster pada tiap-tiap variabel. $\mathrm{Rj}=0,5$.

- q (squash factor), merupakan nilai yang digunakan sebagai pengali dengan jarijari untuk menentukan cluster dengan mengurangi potensi data lainnya. $\mathrm{q}=$ 0,5 .

- Accept ratio yaitu batas bawah di mana suatu titik data yang menjadi kandidat atau calon pusat cluster diperbolehkan untuk menjadi pusat cluster $=0,5$.

- Reject ratio yaitu batas atas di mana suatu titik data yang menjadi kandidat atau calon pusat cluster tidak diperbolehkan untuk menjadi pusat cluster $=0,2$.

- Batas bawah atau minimum data diperbolehkan (Xmin) merupakan nilai minimal untuk data yang akan di cluster $=[0 ; 0 ; 0 ; 0]$

- Batas atas atau maksimum data diperbolehkan (Xmax) merupakan nilai maksimal untuk data yang akan di cluster $=[100 ; 100 ; 5 ; 10]$

c. Normalisasi data, dengan rumus:

$$
\begin{aligned}
& \mathrm{X}_{\mathrm{ij}}=\frac{X_{i j}-X \min _{j}}{X \max _{j}-X \min _{j}} ; \\
& \mathrm{i}=1,2, \ldots, 27 ; \mathrm{j}=1,2,3,4
\end{aligned}
$$

d. Perhitungan Potensi Awal

$\mathrm{Tj}=\mathrm{Xij} ; \mathrm{j}=1,2, \ldots, \mathrm{m}$

Hitung $=$ Dist $_{\mathrm{kj}}=\left(\frac{T_{j}-X_{k j}}{r}\right)$;

$\mathrm{j}=1,2, \ldots, 4 ; \mathrm{k}=1,2, \ldots, 27$ 
Potensi awal:

Karena $\mathrm{m}>1$, maka

$\mathrm{Di}=\sum_{k=1}^{27} e^{-4\left(\sum_{j=1}^{4} D i s t_{k j}^{2}\right)}$

Untuk mempermudah perhitungan, dimisalkan:

$\mathrm{DS}_{\mathrm{k}}=\sum_{j=1}^{4}$ Dist $_{k j}^{2}$

e. Penentuan Pusat Cluster

Apabila $0,2 \leq$ rasio $\left(=\frac{Z}{M}\right) \leq 0,5$ maka data diterima sebagai pusat cluster

f. Menghitung Derajat Keanggotaan

Pusat cluster pertama adalah data ke-23 $\left(\mu_{1-23}=1\right)$; pusat cluster kedua adalah data ke-18 $\left(\mu_{1-18}=1\right)$; pusat cluster ketiga adalah data ke-8 $\left(\mu_{1-8}=1\right)$ p dan pusat cluster keempat adalah data ke-10 $\left(\mu_{1-10}=\right.$ $1)$. Dengan menggunakan fungsi Gauss, dapat dihitung derajat keanggotaan setiap data pada masing-masing cluster.

g. Hasil Akhir Cluster

Cluster ke-1 terdiri dari produk jadi ke-1, 2, 3, 5, 6, 23, 24, 25, 26, dan 27. Cluster ke-2 terdiri dari produk jadi ke-16, 17, 18, 19, 20, 21, dan 22. Cluster ke-3 terdiri dari produk jadi ke-4, 7, 8, dan 9. Cluster ke-4 terdiri dari produk jadi ke-10, 11, 12, 13, 14, dan 15.

\section{Penentuan Prioritas Penempatan Produk}

Penentuan prioritas penempatan produk untuk setiap cluster dilakukan dengan menghitung persentase T/S (throughput per storage). Throughput dan storage dihitung dengan cara sebagai berikut:

1. Throughput $(\mathrm{T})=$ (frekuensi in $\mathrm{x}$ probabilitas in) + (frekuensi out x probabilitas out)

2. Storage $(\mathrm{S})=$ jumlah storage (pallet) yang dibutuhkan

Contoh perhitungan T/S untuk produk Y1192, MBR, FR APRON TO COWL SDE adalah sebagai berikut:

1. Throughput $(\mathrm{T})=(2 \times 0,5)+(24 \times 0,5)=13$

2. Storage $(\mathrm{S})=1$

3. $\mathrm{T} / \mathrm{S}=13 / 1=13$

Penentuan prioritas penempatan produk bertujuan untuk mengetahui cluster mana dan tipe produk apa yang diprioritaskan untuk diletakkan di rak dengan jarak tempuh terpendek dari pintu in dan ke pintu out. Penentuan prioritas penempatan produk dilakukan dengan perhitungan throughput per storage. Perhitungan tersebut didasarkan pada prinsip area penyimpanan berdasarkan popularity-nya, yaitu dengan meminimalisasi jarak tempuh produk yang memiliki frekuensi in dan out yang tinggi (popular item). Semakin tinggi nilai throughput per storage-nya, berarti produk tersebut memiliki frekuensi in maupun out yang semakin tinggi pula, sehingga produk tersebut dikatakan lebih populer dibandingkan tipe produk lainnya.

Tipe produk yang populer memiliki prioritas yang lebih utama atau lebih tinggi untuk ditempatkan di rak yang memiliki jarak tempuh paling minimal dari pintu in dan ke pintu out. Hasil perhitungan throughput per storage menunjukkan bahwa prioritas paling pertama untuk ditempatkan di rak yang memiliki jarak tempuh paling minimal dari pintu in dan ke pintu out adalah cluster 2, selanjutnya di prioritas kedua untuk cluster 4, prioritas ketiga untuk cluster 1, dan prioritas terakhir untuk cluster 3.

\section{Penentuan Layout Alternatif Terbaik}

Alternatif tata letak gudang barang jadi usulan yang terbaik yaitu alternatif ke-4 menghasilkan total biaya perpindahan sebesar Rp 252.982,69 per hari atau penurunan sebesar 4,4132\% dari kondisi awal gudang, dengan total jarak tempuh dari pintu masuk gudang menuju area penyimpanan dan dari area penyimpanan ke pintu keluar gudang sebesar 983,146 meter. Hasil analisa utilisasi gudang menunjukkan adanya peningkatan pada tata letak usulan. Tata letak gudang barang jadi usulan alternatif terbaik menghasilkan utilisasi ruangan sebesar $25,078 \%$.

Hasil perhitungan total biaya perpindahan forklift menggunakan Material Handling Evaluation Sheet terlihat pada Tabel 1.

Material Handling Evaluation Checksheet digunakan sebagai metode evaluasi untuk membandingkan kondisi awal gudang barang jadi dan kondisi pada layout gudang barang jadi usulan. Pada layout gudang barang jadi alternatif ke-4, tidak terdapat lagi delay pada pergerakan material atau produk karena tidak 
ada lagi penempatan produk jadi yang saling menghalangi atau menutupi satu sama lain. Jumlah forklift yang digunakan masih sama seperti kondisi awal gudang barang jadi awal, yaitu 1 buah forklift. Pada layout gudang barang jadi alternatif ke-4 tidak lagi ditemukan lagi penempatan produk jadi di lantai tanpa menggunakan pallet, karena telah dirancang rak yang digunakan untuk menyimpan produk jadi.

Tabel 1. Hasil Perhitungan MHES

\begin{tabular}{ccc} 
Total Biaya & $\begin{array}{c}\text { Persentase } \\
\text { Penurunan }\end{array}$ & \\
$\begin{array}{c}\text { Perpindahan } \\
\text { (Rp) per } \\
\text { Biaya dari } \\
\text { Kondisi } \\
\text { Awal }\end{array}$ & $\begin{array}{c}\text { Alternatif } \\
\text { Terbaik }\end{array}$ \\
\hline $253.014,59$ & 4,4012 & \\
$253.058,86$ & 4,3844 & Alternatif \\
$252.984,68$ & 4,4125 & 4 \\
$252.982,69$ & 4,4132 & \\
$253.121,00$ & 4,3610 & \\
$264.662,84$ & & \\
& &
\end{tabular}

Penempatan produk jadi dilakukan berdasarkan hasil pengelompokkan Fuzzy Subtractive Clustering Algorithm dengan penentuan prioritas berdasarkan throughput per storage-nya, sehingga penempatan produk jadi menjadi teratur, terpusat, dan jarak tempuh forklift dapat diminimalkan. Penempatan produk jadi yang teratur menyebabkan jalur gang tidak lagi terganggu. Jalur gang pada gudang barang jadi masih berupa jalur gang 2 arah, namun lebarnya disesuaikan dengan forklift yang digunakan, yaitu selebar 3,5 meter. Sehingga, forklift dapat leluasa bergerak dan melakukan turnover. Pada layout gudang barang jadi alternatif ke-4, tidak ada lagi area pada gudang barang jadi yang difungsikan di luar kegiatan penyimpanan produk jadi.

\section{Visualisasi Gudang Barang Jadi Menggunakan ProModel}

Pembuatan visualisasi bertujuan untuk menunjukkan pergerakan forklift dalam proses pengangkutan produk jadi stamping parts dari lantai produksi menuju ke area penyimpanan dan dari area penyimpanan menuju keluar gudang barang jadi dengan menggunakan software ProModel. Visualisasi dibuat pada layout kondisi awal gudang barang jadi dan layout gudang barang jadi usulan alternatif ke-4 (alternatif terbaik). Tipe-tipe stamping parts yang divisualisasikan adalah tipe-tipe stamping parts yang termasuk dalam klasifikasi A pada klasifikasi ABC. Tipe-tipe stamping parts yang tergolong dalam klasifikasi A tersebut dianggap dapat mewakili seluruh pergerakan stamping parts oleh forklift.

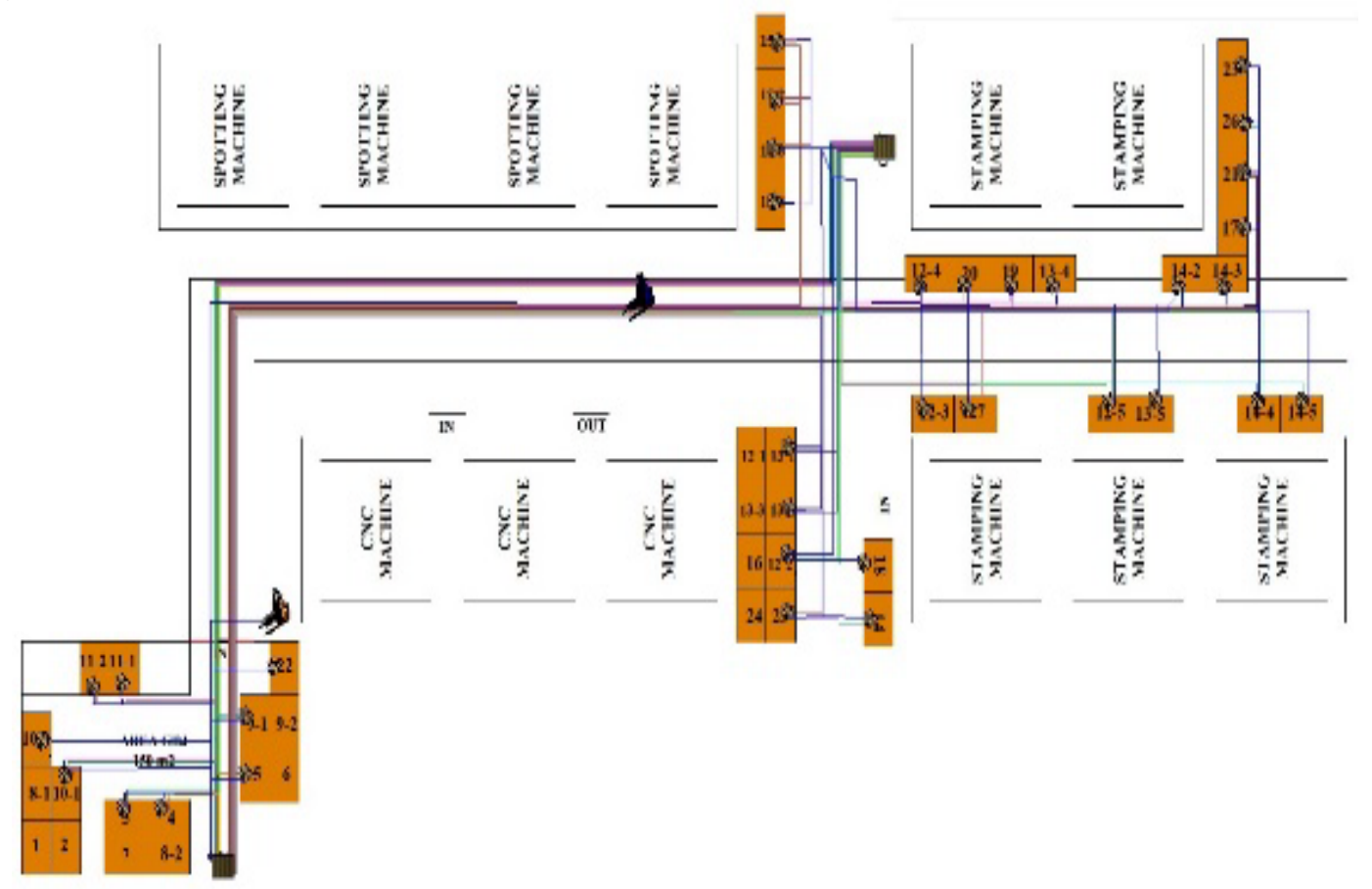

Gambar 10. Visualisasi Kondisi Awal Gudang Barang Jadi 


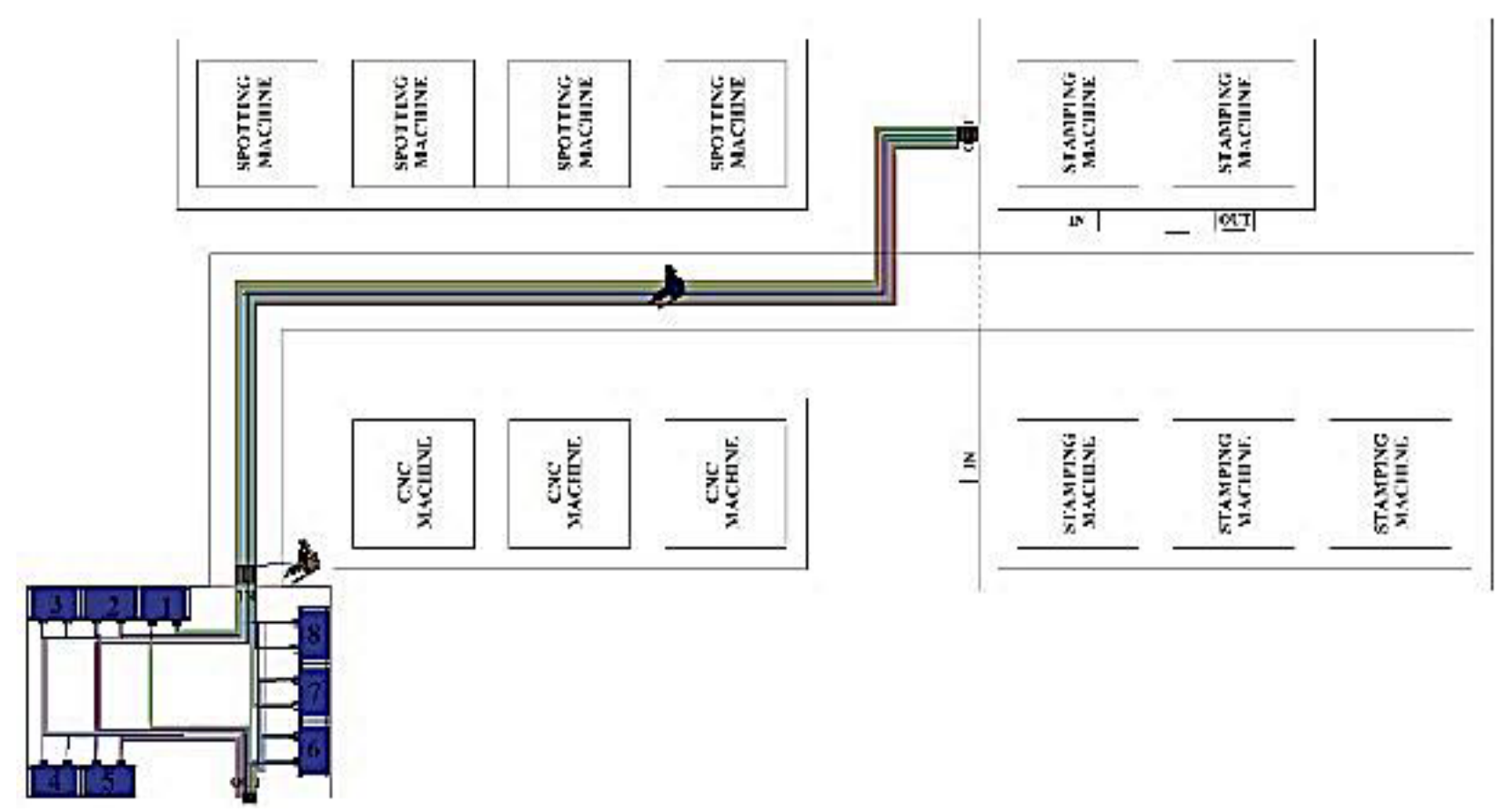

Gambar 11. Visualisasi Layout Usulan ke-4

Berdasarkan hasil visualisasi perpindahan stamping parts pada kondisi awal gudang dan tata letak usulan, diperoleh hasil bahwa total waktu perpindahan layout gudang barang jadi alternatif ke-4 lebih pendek daripada total waktu perpindahan layout kondisi awal gudang barang jadi. Total waktu perpindahan gudang barang jadi berkurang dari 1,76 jam (pada layout kondisi awal gudang barang jadi) menjadi 0,51 jam (layout gudang barang jadi alternatif ke-4). Tata letak usulan mampu mengurangi waktu perpindahan stamping parts sebanyak 1,25 jam.

\section{KESIMPULAN}

Berdasarkan hasil penelitian dapat disimpulkan bahwa: perancangan tata letak gudang barang jadi menggunakan metode Fuzzy Subtractive Clustering Algorithm menghasilkan 4 cluster dengan cluster 2 sebagai cluster dengan prioritas pertama untuk ditempatkan di rak dengan jarak tempuh terpendek. Alternatif tata letak gudang barang jadi terbaik berdasarkan total biaya perpindahan produk jadi paling minimum adalah alternatif ke-4 dengan total biaya perpindahan produk jadi per hari sebesar Rp 252.982,69 (penurunan 4,413\% dari kondisi awal) dan total jarak tempuh forklift berkurang menjadi 983,146 meter. Utilitas penggunaan ruang pada tata letak gudang barang jadi usulan meningkat menjadi sebesar $25,078 \%$.

\section{DAFTAR PUSTAKA}

[1]. Tompkins, White, Bozer, Frazelle, Tanchoco, \& Trevino. 2003. Facilities Planning. $3^{\text {rd }}$ Edition, John Wiley \& Sons, Canada.

[2]. Mulcahy, D.E. 1994. Warehouse And Distribution Operations Handbook. McGraw Hil-Hill Book Co., Singapore.

[3]. Kusumadewi, S., Purnomo, H. 2013. Aplikasi Logika Fuzzy Untuk Pendukung Keputusan. $2^{\text {nd }} \cdot$ Edition, Graha Ilmu, Yogyakarta.

[4]. Bataineh, K.M.., Naji, M., \& Saqer, M. 2011. A Comparison Study Between Various Fuzzy Clustering Algorithms. Jordan Journal of Mechanical and Industrial Engineering, 5(4).

[5]. Harrel, Charles , Biman K. Ghosh, Royce O. Bowden Jr. 2003. Simulation Using Promodel. Second Edition. Mc. Graw Hill International Edition. New York.

[6]. Priyono, A., Ridwan, M., Alias, A.J., Rahmat, R.A.O.K, Hassan, A., Ali., M.A.M. 2005. Generation of Fuzzy Rules with Subtractive Clustering. Jurnal Teknologi: 43(D) 
Rancangan Perbaikan Tata Letak Gudang Barang Jadi Produk Stamping Parts pada PT. CSM Berdasarkan Metode Fuzzy Subtractive Clustering Algorithm

Annisa Widya Putri dan Iveline Anne Marie

[7]. Steelking Industries, Inc., 2015. Pallet Rack SK2000 Capacity. [Online] Available at: http://www.steelking.com [accessed 15 Desember 2014] 